\title{
УДК 37.02:004.9
}

\section{Гаврілова Людмила Гаврилівна}

доктор педагогічних наук, доцент, завідувач кафедри теорії і практики початкової освіти ДВНЗ «Донбаський державний педагогічний університет», м. Слов'янськ, Україна ORCID ID 0000-0003-1814-5323

lusjamuz64@gmail.com

Топольник Яна Володимирівна

кандидат педагогічних наук, доцент, доцент кафедри педагогіки вищої школи ДВНЗ «Донбаський державний педагогічний університет», м. Слов’янськ, Україна ORCID ID 0000-0001-7885-9454

yannetkatop@gmail.com

\section{ЦИФРОВА КУЛЬТУРА, ЦИФРОВА ГРАМОТНІСТЬ, ЦИФРОВА КОМПЕТЕНТНІСТЬ ЯК СУЧАСНІ ОСВІТНІ ФЕНОМЕНИ}

\begin{abstract}
Анотація. У статті здійснено аналіз сучасних освітніх дефініцій: цифрова культура, цифрова грамотність та цифрова компетентність. На основі вивчення вітчизняних i зарубіжних наукових джерел, державних нормативно-правових документів автор доводить, що названі поняття виходять за межі технологічної або цифрової галузі. Вони торкаються широкого кола освітніх, культурологічних, соціогуманітарних та ін. аспектів. Основні смислові акценти цифрової культури пов'язані 3 виникненням нових специфічних інформаційно-віртуальних форм культури та культурної комунікації. Цифрова грамотність вказує передусім на досконале користування електронними засобами, на сформованість умінь і навичок роботи 3 «цифрою». Визначення цифрової компетентності виходить із загального розуміння компетентності й складається 3 відповідних знань, умінь, досвіду, цінностей і ставлень, що можуть цілісно реалізовуватися на практиці.
\end{abstract}

Ключові слова: цифрова компетентність; цифрова грамотність; цифрова культура; знання; уміння; навички; ставлення.

\section{1. ВСТУП}

Постановка проблеми. Розвиток сучасного інформаційного суспільства, інтенсивне оновлення й переформатування системи вітчизняної освіти, яка наразі все більше залежить від занурення іiі суб'єктів до інформаційно-комунікаційного (комп'ютерного, мультимедійного, цифрового) середовища, призводить до поступового оновлення понятійного апарату, уведення до наукового обігу нових дефініцій й переосмислення наявних. Аналізуючи певні освітні проблеми, пов'язані 3 використанням комп'ютерних технологій, вітчизняні і зарубіжні науковці все частіше вживають поняття «цифрової компетентності», «цифрової грамотності», «цифрової культури педагога», які стають своєрідними індикаторами професійної підготовки сучасного вчителя.

Аналіз останніх досліджень і публікацій. Зважаючи на підписання Україною Угоди про Асоціацію з Свропейським Союзом, основні цілі розвитку інформаційного суспільства в Україні поступово узгоджуються з орієнтирами європейського розвитку. Серед них - ініціатива «Цифровий порядок денний для Європи» («Digital agenda for Europe»), яка визначає пріоритетні позиції розбудови інформаційного суспільства в рамках європейської стратегії економічного розвитку «Європа 2020: стратегія розумного, сталого і всеосяжного зростання» («Europe 2020: Astrategy for smart, sustainable and inclusive growth»). 3 метою інтеграції у світові процеси «цифровізації» у 2016 році Кабінет Міністрів України презентував проект «Цифровий порядок денний 
України 2020» («Digital Agenda for Ukraine 2020») [1]. Серед першочергових сфер та ініціатив цифровізації України - поширення цифрової освіти. У названому документі широко вживані поняття «цифрової грамотності», «цифрової компетентності», «цифрового інтелекту», зокрема вказано на актуальність формування наскрізної (кросплатформової) цифрової компетентності, коли вивчення предметів відбувається через використання «цифрових» технологій [1, с. 22]

3 урахуванням процесів цифровізації як у глобальному, так і національному масштабі, наразі розпочалося реформування середньої освіти України, у 2016 році представлено проект нового освітнього стандарту «Нова українська школа». До понятійного апарату цього документу, відповідно до сучасних вимог, включено інформаційно-цифрову компетентність як одну 3 ключових серед груп компетентностей, окреслених у «Рекомендаціях європейського Парламенту та Ради Європи», що мають стати наскрізними у змісті всіх навчальних предметів. Інформаційно-цифрова компетентність, на думку авторів нового освітнього стандарту, передбачає впевнене й водночас критичне застосування інформаційно-комунікаційних технологій (IКТ) для створення, пошуку, обробки, обміну інформацією на роботі, в публічному просторі та приватному спілкуванні. Вона також вміщує інформаційну й медіа-грамотність, основи програмування, алгоритмічне мислення, уміння працювати 3 базами даних, навички безпеки в Інтернеті та кібербезпеці, а також розуміння етики роботи з інформацією (авторське право, інтелектуальна власність тощо) [2, с. 13]. Тож смислове поле поняття «інформаційно-цифрова компетентність» акцентує саме цифрові аспекти інформаційних знань, умінь, навичок і ставлень.

Разом із нормативно-правовим обгрунтуванням оновлення понятійного апарату освіти, зокрема у напрямі ii цифровізації, відбувається й наукове осмислення та потрактування цілої низки дефініцій. Зарубіжні автори (Д. Белшоу (D. Belshaw), Б. Гірш (B. Hirsch), Г. Крибер та P. Мартін (G. Creeber\&R. Martin), Л. Манович (L. Manovich), Дж. Стоммел (J. Stommel) та iн.), вітчизняні науковці (В. Биков, Д. Галкін, М. Лещенко, П. Матюшко, О. Овчарук, В. Ребрина та ін.) розтлумачують категорії «цифрової грамотності», «цифрової компетентності», «цифрової культури» та дотичні до них поняття, визначають їх структуру та специфічні особливості, пов'язані зі стрімким розвитком сучасних інформаційно-комунікаційних технологій.

Мета статті. Здійснення аналізу сучасного розуміння педагогічного феномену «цифрової компетентності», а також близьких до нього понять «цифрової грамотності» та «цифрової культури» й окреслення специфіки їх застосування.

\section{2. ТЕОРЕТИЧНІ ОСНОВИ ДОСЛІДЖЕННЯ}

Науково-теоретичні засади дослідження складають базові підходи педагогічної науки, передусім компетентнісний підхід як один зі стратегічних напрямів державної політики в освітній сфері, що орієнтує на досягнення певного освітнього результату. У тлумаченні його фундаментальних категорій, диференціації понять «компетентність» та «компетенція», визначенні базових і ключових компетентностей ми виходимо 3 положень вітчизняної педагогіки, наукових розвідок Н. Бібік, Т. Байбари, М. Голованя, I. Зимньої, В. Краєвського, О. Локшиної, В. Лозової, О. Овчарук, О. Онопрієнко, О. Пометун, О. Савченко, А. Хуторського та багатьох інших.

Вивчення педагогічних феноменів «цифрової грамотності», «цифрової компетентності», «цифрової культури» має нормативно-правові підвалини: європейські та вітчизняні державні документи («Рекомендації Європейського Парламенту та Ради Європи щодо формування ключових компетентностей ціложиттєвої освіти» (2006), 
«Стратегія розвитку інформаційного суспільства в Україні» (2013), Закон України «Про вищу освіту» (2014) та ін.).

Важливим теоретичним підгрунтям дослідження $\epsilon$ зарубіжні й вітчизняні концепції, сучасні ініціативи в галузі глобалізації й інформатизації освіти, наукові розвідки зі створення і застосування засобів ІКТ в педагогічній діяльності (В. Биков, М. Жалдак, М. Лещенко, Л. Петухова, I. Роберт, О. Співаковський, О. Спірін, М. Шишкіна, А. Яцишин та ін.).

\section{3. МЕТОДИКА ДОСЛІДЖЕННЯ}

Для проведеного дослідження було використано комплекс методів, серед яких аналіз, синтез, порівняння, узагальнення для вивчення наукової літератури й державних нормативно-правових документів та для порівняння позицій учених щодо змісту понять «цифрова компетентність», «цифрової грамотність» та «цифрова культура».

\section{4. РЕЗУЛЬТАТИ ДОСЛІДЖЕННЯ}

Аналіз наукових праць засвідчує інтерес учених до нових тенденцій інформатизації навчального процесу, зокрема його «цифровізації». У наукових розвідках останніх років з'явилося чимало нових та оновлених понять і термінів, так чи інакше пов'язаних з упровадженням інформаційно-комунікаційних технологій в освіту. Серед них:

- «цифрове навчання» (digital learning) як система навчання за допомогою інформаційних, електронних технологій (синонім електронного навчання, e-learning), що дозволяє забезпечувати викладання навчальних курсів, отримувати інформацію та спілкуватися викладачам і студентам між собою незалежно від часу та місця знаходження;

- «онлайн педагогіка» (online pedagogy), яка передбачає онлайн-навчання 3 викладачем (тьютором, фасилітатором);

- «гібридна педагогіка» (hybrid pedagogy) як синонім змішаного навчання (blended learning) - комбінування педагогічних теорій і технологій, що дозволяє поєднувати традиційне навчання в аудиторії з онлайн-навчанням;

- «критична цифрова педагогіка» (critical digital pedagogy), що передбачає відкритість шляхів спілкування і співпраці, у тому числі міжнародне співробітництво через культурні та політичні кордони; вихід за межі традиційних інститутів освіти; врахування поглядів усіх учасників навчального процесу (Дж. Стоммел [3]).

Науковці (В. Биков, М. Лещенко, П. Матюшко, М. Чошанов та ін.) засвідчують відгалуження самостійної педагогічної гілки - цифрової педагогіки (digital pedagogy) як науки про використання електронних елементів у навчальному процесі 3 метою посилення та зміни освітянського досвіду, що призводить до переформатування навчання i викладання. Цілком поділяючи думку В. Бикова та М. Лещенко[4], наголосимо, що цифрова педагогіка - це наука про закономірності передачі та сприймання освітнього досвіду, що відбувається у фізичній і віртуальній реальностях на основі використання інформаційно-комунікаційних технологій. Як влучно вказує П. Матюшко, цифрова педагогіка грунтується на дії, інтерактивності, співробітництві, впровадженні у навчання технологічних досягнень (віртуальна реальність, штучний інтелект, великі бази даних, відео 360 градусів та ін.), вона має ігровий емоційний характер. Наразі сучасна освіта знаменується процесом переходу від навчання 2.0, де обмін і співробітництво $є$ основоположними, до навчання 3.0, яке використовує 
принципово нові технології [5]. М. Чошанов виокремлює основні компоненти цифрової педагогіки - електронну дидактику та проектування педагогічних процесів [6].

Відзначимо також широке поширення в зарубіжних дослідженнях понять цифрова компетентність (digital competence), цифрова грамотність (digital literacy), компетентність у сфері IKT (ICT competence), інформаційно-комунікаційнотехнологічна грамотність (ICT literacy), цифрова культура (digital culture), які почасту використовуються як синонімічні для визначення професійної компетентності педагога у сфері ІКТ та його готовності до застосування цифрових технологій у професійнопедагогічній діяльності. Розглянемо тлумачення найпоширеніших із цих понять докладніше.

\section{1. Цифрова культура}

Поняття «цифрової культури» було введено до наукового обігу в 2000-х роках (2004 p., T. O'Рейлі (T. O'Reilly) у зв'язку з виникненням технологій Web 2.0 - другого покоління мережевих сервісів Інтернету 3 якісно новим підходом до організації, реалізації та підтримки Web-pесурсів. Відзначимо досить широке його потрактування.

Переважна більшість досліджень акцентує культурологічний та соціокультурний аспекти цифрової культури. Приміром, в Аналітичній записці відділу гуманітарної політики Національного інституту стратегічних досліджень [7] зазначено, що цифрова культура $є$ базовою основою сучасної світової культури, невід'ємною складовою усіх без виключення суспільних процесів, у тому числі й освітніх; явище цифрової культури $\epsilon$ знаковим, оскільки вказує на домінуючу форму соціалізації сучасного суспільства інформаційно-віртуальну. Документ засвідчує докорінні зміни у розумінні власне культури, яка набуває нових форм (кінематографічний i літературний кіберпанк, відеоскульптура й цифрові інсталяції, техно- та електронна музика, віртуальний музей та театр, софт-арт) і демонструє фундаментальні зміни у пізнанні людини та іiі творчості.

У дослідженні Н. Соколової [8] відзначається складність і багатозначність досліджуваного феномена, його стрімкий розвиток і видозмінення, що підтверджує еволюція дефініцій, використовуваних для аналізу й усвідомлення цифрових технологій («цифрові» або «нові медіа», «кіберпростір культури», «кіберкультура», «цифрова культура», «пост-кіберкультура»).

Інші науковці (Д. Галкін [9], С. Черних та В. Паршиков [10]) занурюються до простору цифрової культури, аналізуючи нові артефакти, нові практики, які виникли саме завдяки цифровим технологіям (комп'ютерна графіка, комп'ютерні ігри, Інтернет, системи віртуальної реальності, цифрові формати традиційних засобів комунікації, технологічне мистецтво тощо) і загальні еволюційні процеси «оцифровування» сучасної культури. Вони вбачають у цифровій культурі, яка визначає нові цінності та смисли буття особистості, опозицію гуманістичній педагогіці, говорять про нову онтологію освітньої взаємодії і встановлення нового освітнього порядку, коли змінюється не лише алгоритм «набуття» знання, а й власне культура цього набуття й використання знань [10].

Д. Галкін вважає за доцільне розглядати цифрову культуру на декількох рівнях:

- матеріальному (технічні системи сучасних цифрових пристроїв: комп’ютери, смартфони, цифрові фотокамери з відповідним ПЗ);

- функціональному (соціальному): забезпечення діяльності інститутів, які визначають спосіб повсякденного життя, форми взаємодії, ритуали і традиції різних груп населення (від ведення електронної документації до творів технологічного мистецтва); 
- символічному, оскільки символічна природа цифрової культури, яка формується в логіці цифрового кодування і розвитку мов програмування, не викликає сумнівів;

- ментальному, який стосується вкоріненості культури в психічне життя людей (цей рівень цифрової культури торкається дискусійних питань прийняття чи відкидання технологічного імперативу, нових звичок роботи з інформаційними даними тощо);

- д духовно-ціннісному, що вміщує цінності цифрової культури в національному, міжнаціональному, релігійному, соціально-політичному, метафізичному контекстах [9].

Як сучасний культурологічний феномен поняття цифрової культури аналізують $\mathrm{i}$ зарубіжні науковці К. Бассет (С. Bassett), К. Гере (С. Gere), Г. Грибер (G. Creeber), M. Деузе (M. Deuze), Р. Мартін (R. Martin), М. Хенд (M. Hand), почасту ототожнюючи його $з$ новими медіа. За влучним висловлюванням К. Гере (C. Gere), дигітальністьє маркером культури останніх десятиліть, вона включає й артефакти, і комунікації, й ознаки, типові для сучасного способу життя [11].

У сучасній науці (Л. Баєва [12], О. Гук [13], В. Кривошеєв [14]) також існує тенденція тлумачити цифрову культуру як технологічний феномен, оскільки всі об'єкти цієї культури функціонують 3 допомогою цифрових пристроїв на основі принципу цифрового кодування інформації 3 допомогою бінарного коду, що стає системоутворювальним чинником цієї культури (з технологічного боку). У цьому випадку поняття «цифрової культури» збігається 3 дефініцією «електронної культури» (е-культури) як сукупності результатів творчості та комунікації людей в умовах впровадження IT-технологій, утворення єдиного інформаційного простору. Оскільки всі сучасні інформаційно-комунікаційні засоби (комп'ютер, мобільний телефон, кіно- і телекамера, аналогові й цифрові відеокамери, плеєри, планшети, фотоапарати та ін.) є електронними пристроями, смислове поле електронної культури вміщує також феномени комп'ютерної, мультимедійної, кіберкультури як ії різновиди (О. Гук [13]).

Інші аспекти цифрової культури акцентує К. Літвінова (К. Litvinova) у власному DigitleBlog, розуміючи ïi як систему правил поведінки людини, яких вона дотримується під час використання інформаційно-комунікаційних технологій [15]. До компонентів цифрової культури авторка відносить:

- раціональне споживання інформації;

- $\quad$ критичне мислення, що стосується кількості та якості сприйнятої інформації $\mathrm{i}$ вміщує пошук (вибір достовірних та надійних інформаційних джерел), інтерпретацію (надання переваги фактам, ніж думкам), дослідження (глибокий аналіз інформації для формування висновків) й оцінку (погляд на інформаційне повідомлення 3 різних аспектів);

- цифрову грамотність, тобто вміння користуватись сучасними IT та програмним забезпеченням, особливо у професійній діяльності;

- ІТ-волонтерство - використання ІКТ не лише для власних потреб, але й для вдосконалення оточуючого світу;

- «зелене» використання інформаційних технологій («Greening IT»), участь у вирішенні екологічних проблем, спричинених інформаційним прогресом [15].

Поняття «цифрова культура педагога» у науковій i методичній літературі використовується переважно як синонім цифрової грамотності, приміром, В. Цебрина [16] визначає цей освітній феномен як уміння працювати із сучасною цифровою технікою i володіти сучасними інформаційно-комунікаційними технологіями та виокремлює такі його складники: комп'ютерна грамотність, інформаційна грамотність (інформаційна культура), мультимедійна грамотність та грамотність комп'ютерної комунікації. 


\section{2. Цифрова грамотність}

Поняття цифрової грамотності (digital literacy) є широко вживаним у зарубіжній педагогіці. На початку XXI століття з розвитком Інтернету зарубіжними науковцями (П. Гілстер (P. Gilster), Г. Дженкінс (H. Jenkins), М. Варшавер (М. Warschauer) та Т. Матучняк (Т. Matuchniak), А. Мартін (А. Martin), Е. Харгітай (Е. Hargittai) та ін.) було сформульовано концепцію «цифрової грамотності» як системи когнітивних, соціальних i технічних навичок, які гарантують якісне існування людини в інформаційному середовищі. Наразі дослідники розглядають цифрову грамотність як більш складне поняття, яке характеризується комплексом складників, серед яких:

- комп'ютерна грамотність (computer literacy) як ефективне використання електронних пристроїв та програмного забезпечення;

- інформаційна грамотність (information literacy) - навички самостійного пошуку, аналізу, критичного осмислення інформаційних даних;

- компетентне користування соціальними медіа (socialmedia literacy);

- використання мережевих технологій (network literacy) 3 розумінням основ мережевої безпеки і стандартів нетикету.

Як влучно зазначають Н. Корецька та О. Мороз [17], сучасне розуміння цифрової грамотності європейськими й американськими дослідниками обов'язково вміщує екологічне відношення до цифрових технологій як особливого середовища життя людини, що вимагає дотримання норм гігієни й відповідальності користувача.

Г. Дженкінс(H. Jenkins) та ін. [18] вважають, що цифрова грамотність залежить від сформованості трьох типів навичок:

- навички взаємодії 3 комп'ютером та будь-якими іншими пристроями (hardwareskills), з допомогою яких можна вийти в Мережу або створювати цифрові артефакти;

- навички взаємодії 3 програмним забезпеченням (software skills), що забезпечують можливості роботи з контентом.

- універсальні навички роботи з цифровими технологіями (meta skills), зокрема конструювання, розроблення цифрового онлайн чи офлайн середовища.

Зупинимось на тлумаченні цифрової грамотності Д. Белшоу (D. Belshaw) у книзі «Основні елементи цифрової грамотності» (The Essential elements of digital literacies) [19], який засвідчує наявність різних моделей цього феномену й виокремлює вісім ключових компонентів як основу якісної взаємодії людини 3 «цифрою» (культурний, когнітивний, конструктивний, комунікативний, критичний, громадянський, а також упевнене користування та креативність). Компоненти унаочнені у вигляді схеми (рис. 1).

Вважаємо за необхідне деталізувати кожен із компонентів.

1. Культурний компонент, на думку Д. Белшоу, передбачає дотримання нетикету (netiquette) - правил поведінки в Мережі, культури інтернет-спілкування, розуміння специфічних інтернет-артефактів (інтернет-мем (Internetmeme), емодзі (етојі), анімовані gif-файли тощо); розуміння історії, мови, звичаїв та цінностей цифрових середовищ, повагу до принципів конфіденційності та захисту інформації; визнання різниці між особистим і професійним користуванням цифровими засобами та iн.

2. Когнітивний компонент, за Д. Белшоу, це розуміння ключових понять комп'ютерної грамотності, володіння ІТ-навичками, усвідомлення спільних функцій (навігаційних меню, настроювань, профілів), тегів, хеш-тегів у цифрових засобах, що загалом забезпечує можливість користування цифровими пристроями, програмними платформами та інтерфейсами. 
3. Конструктивний компонент - знання умов коректного використання контенту під час «конструювання» будь-чого в цифровому середовищі, дотримання авторських прав і знання різних ліцензій Creative Commons.

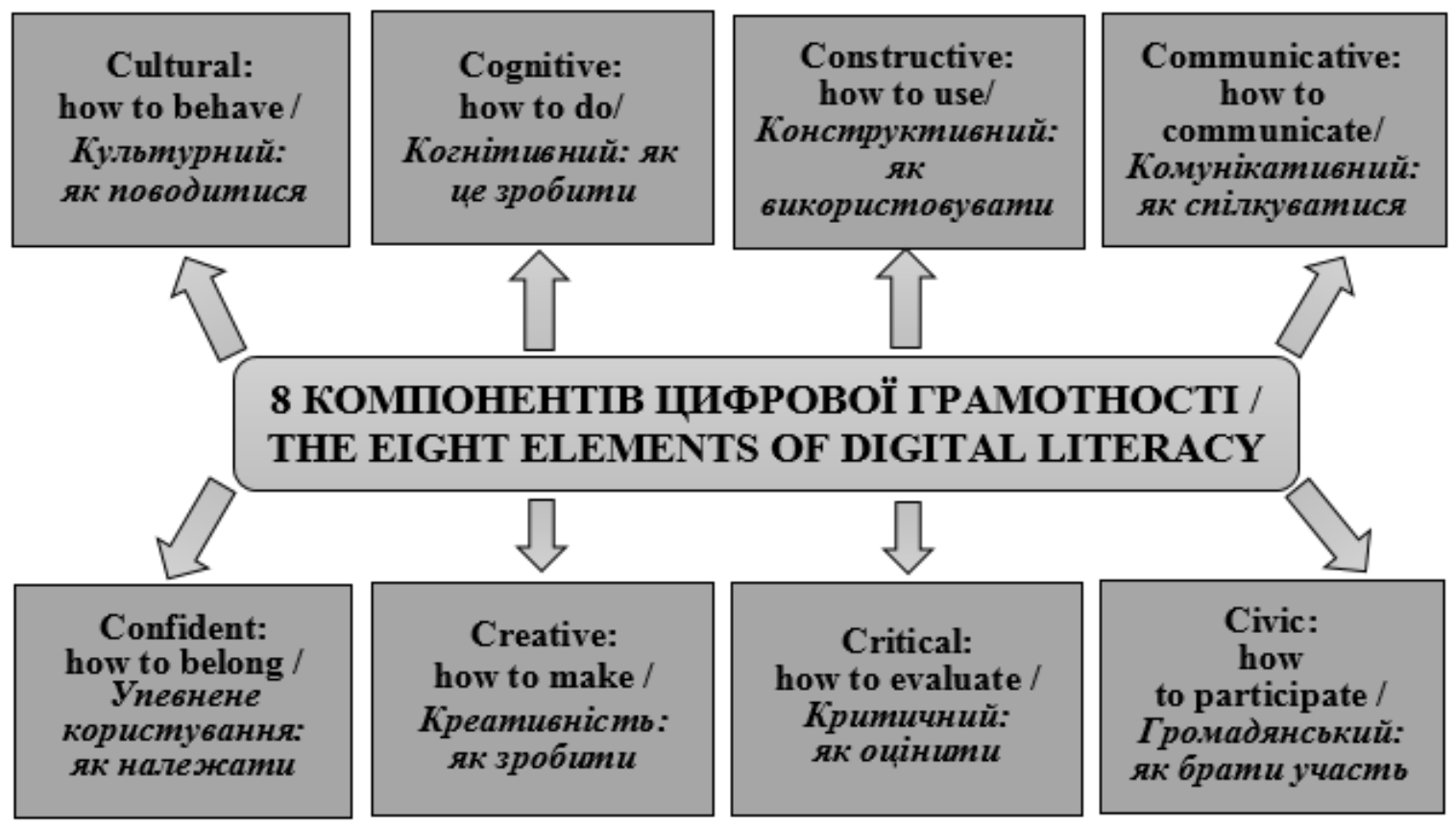

Рис. 1. Компоненти цุифрової грамотності (за Д. Белшоу)

4. Комунікативний компонент припускає знання можливостей спілкування в цифрових середовищах, розуміння специфіки понять «ідентичність», «довіра», «обмін», «вплив» у цифровому просторі.

5. Виокремлений Д. Белшоу компонент «Упевнене користування» передбачає відчуття себе частиною онлайн-спільноти, розуміння й використання переваг онлайнпростору порівняно 3 оффлайн-світом, а також відображає навчання в цифровому середовищі.

6. Креативність у складі цифрової грамотності вказує на цінність творчості в цифровому просторі, опанування нових способів використання онлайн-інструментів та середовищ, створення нового знання за допомогою цифрових технологій.

7. Використання аналітичних умінь і навичок оцінювання цифрового контенту, інструментів та програм, виокремлення надійних джерел характеризують критичний компонент цифрової грамотності за Д. Белшоу

8. Громадянський компонент характеризує осіб, які використовують цифрові середовища для самоорганізації, а також відстоюють цифрові права та обов'язки, беруть участь у соціальних рухах в Інтернеті, готують себе та інших до участі у реальному суспільному житті [19].

Феномен цифрової грамотності вивчається і російськими вченими (Н. Корецька, О. Мороз та ін.). Приміром, О. Шаріков пропонує чотирикомпонентну модель названої дефініції, яка складається з двох конструктів-опозицій.

1. Техніко-технологічне / соціогуманітарне.

2. Можливості / загрози.

У семантичному просторі названих конструктів дослідником виокремлюються 4 компоненти: техніко-технологічні можливості (утилітарні, прагматичні, інструментальні компетенції); змістовно-комунікативні можливості (розвиток 
здібностей зі створення медіатекстів, їх оцінювання, інтерпретація іншими користувачами, спілкування у Мережі); техніко-технологічні загрози (безпека у Мережі) та соціопсихологічні загрози (соціальні, етичні, психологічні аспекти роботи в цифровому середовищі). Таке структурування цифрової грамотності, на думку дослідника, може стати основою для моніторингу стану її сформованості [20].

Вітчизняні дослідники також не обходять увагою означений феномен, розглядаючи його в межах культурології, соціології, процесів інформатизації в освіті. О. Овчарук [21] розглядає цифрову грамотність як складову ІК-компетентності; В. Кудлай [22] та О. Радзієвська [23] це поняття пов’язують передусім з проблемами інтернет-безпеки.

Близькими, почасту синонімічними до цифрової грамотності, $\epsilon$ поняття технологічної грамотності (technology literacy), інформаційної грамотності (information literacy), IКТ-навичок (ICT skills), а також більш загальне поняття IК-компетентності.

\section{3. Цифрова компетентність}

Поняття «цифрова компетентність» порівняно 3 проаналізованими вище дефініціями «цифрової культури» та «цифрової грамотності» $є$ значно ширшим і більш загальним, оскільки його смисловий контент вміщує і навички роботи в інформаційнокомунікаційному (цифровому) середовищі як провідну ознаку цифрової грамотності, i соціокультурну складову (нові артефакти, нові практики цифрової культури 3 відповідними ціннісними орієнтирами та особистісним досвідом).

У тлумаченні цифрової компетентності зарубіжними і вітчизняними науковцями слід відзначити деякі розбіжності. Наприклад, С. Скотт (C. Scott) [24] розуміє цифрову компетентність як здатність використовувати цифрові медіа й IКТ, розуміти і критично оцінювати різні аспекти цифрових медіа і медіа контенту, а також уміти ефективно комунікувати у різноманітних контекстах. Серед виокремлених науковцем складників: інформаційна і медіа грамотність (пошук, опрацювання, зберігання інформації, створення цифрових матеріалів); онлайн комунікація (електрона пошта, чати, блоги, соціальні мережі та ін.); технічний (ефективне і безпечне використання комп'ютера і ПЗ для вирішення різноманітних задач) та споживацький (вирішення повсякденних задач, які задовольняють різноманітні потреби) компоненти [24]. Отже, у даному випадку цифрова компетентність не виходить за межі схарактеризованих раніше «цифрової культури» та «цифрової грамотності».

A. Мартін (A. Martin) [25] вважає цифрову компетентність першим рівнем розвитку цифрової грамотності, тобто вибудовує протилежну підпорядкованість понять

К. Ала-Мутка (K. Ala-Mutka), вивчаючи офіційні документи Європейського Союзу з питань освіти та наукові розвідки вчених, побудувала узагальнюючу модель цифрової компетентності [26], складниками якої стали:

- інструментальні вміння та знання (instrumental skills and knowledge), а саме технічні уміння роботи з цифровими пристроями, а також знання і вміння безпечного використання медіа-середовищ;

- просунуті (поглиблені) уміння та знання (advanced skills and knowledge), що передбачають ефективну взаємодію та комунікацію, управління інформацією, навчання в мережі, участь у цифровій діяльності;

- ставлення (attitudes), зокрема розуміння й прийняття міжкультурної взаємодії, критичне ставлення до якості інформації, відкритість до цифрової творчості й навчання 3 використанням цифрових інструментів, розуміння й урахування проблем інтернетбезпеки, дотримання етики цифрового середовища [26]. 
Тож К. Ала-Мутка, узагальнюючи європейський досвід, зробила акценти на цифрових знаннях i уміннях (когнітивному й технологічному компонентах), сформованість яких фактично $є$ проявом цифрової грамотності, а також на комунікативному, соціокультурному, етичному аспектах, які характеризують, передусім, цифрову культуру користувачів.

Доцільно навести узагальнене визначення цифрової компетентності, що було сформульовано А. Феррарі (A. Ferrari) на основі грунтовного аналізу кількох національних і міжнародних проектів та ініціатив: це набір знань, умінь, ставлень (включаючи здатності, стратегії, цінності та обізнаність), що необхідні для використання інформаційно-комунікаційних технологій та цифрових медіа 3 метою виконання завдань; вирішення проблем; спілкування; управління інформацією; співробітництва; створення і поширення змісту; та побудови знання ефективно, результативно, відповідно, критично, творчо, самостійно, гнучко, етично, рефлексивно для роботи, відпочинку, спільної діяльності, навчання, спілкування, задоволення споживчих потреб та забезпечення можливостей для реалізації прав [27]. Вважаємо це визначення найбільш повним і точним, воно стало основоположним для тлумачення поняття інформаційно-цифрової компетентності у проекті нового освітнього стандарту «Нова українська школа».

Слід відзначити, що цифрова компетентність $\epsilon$ на сьогодні найширшим поняттям серед низки понять, використовуваних у сфері інформаційно-комунікаційних (комп'ютерних, цифрових) технологій. Проте у вітчизняній науці воно лише набуває поширення й теоретичного осмислення, застосовуючись переважно як синонім інформаційної грамотності (С. Прохорова [28]) або ІКТ-компетентності (О. Овчарук [21]).

\section{5. ВИСНОВКИ ТА ПЕРСПЕКТИВИ ПОДАЛЬШИХ ДОСЛІДЖЕНЬ}

Огляд численних наукових джерел 3 питань глобалізації й інформатизації освітнього процесу, використання IКТ у професійній підготовці фахівців, так званої «цифровізації» вітчизняної освіти засвідчив поступове оновлення понятійного апарату та дозволив зробити деякі узагальнення щодо цифрової компетентності, цифрової грамотності та цифрової культури педагога.

1. Поняття «цифрової культури», «цифрової грамотності» та узагальнююче поняття «цифрової компетентності» в сучасних дослідженнях виходять за межі технологічної або цифрової галузі. Вони торкаються широкого кола культурологічних, соціогуманітарних, комунікативних, ціннісних, етичних та ін. аспектів.

2. Категорія цифрової культури у сучасній науковій літературі аналізується, передусім, як культурологічний, соціологічний, технологічний феномен. Основні смислові акценти зроблені на функціонуванні 3 допомогою цифрових пристроїв, виникненні нових специфічних інформаційно-віртуальних форм культури (NetArt, комп'ютерна музика, віртуальні інсталяції тощо), а також нових видів культурної комунікації (web-спілкування) та діяльності (IT-волонтерство, «GreeningIT» та ін.). Осмислення цифрової культури як показника успішної педагогічній діяльності фактично переводить це поняття у смислове поле цифрової грамотності.

3. Цифрова грамотність як широковживана дефініція зарубіжної педагогіки вказує передусім на досконале користування електронними засобами, на сформованість умінь і навичок роботи 3 «цифрою». Утім, деякі дослідники вкладають у їі тлумачення характеристики, що наближають це поняття до IT-компетентності.

4. Цифрова компетентність найчастіше визначається на основі загальноприйнятого розуміння компетентності як інтегрованої здатності особистості, 
яка складається із знань, умінь, досвіду, цінностей і ставлення, що можуть цілісно реалізовуватися на практиці. Це поняття є узагальнюючим для попередніх, оскільки сформована цифрова компетентність вміщує i цифрову грамотність, i цифрову культуру.

Окреслені поняття наразі залишаються дискусійними серед європейської наукової спільноти й потребують подальшого грунтовного вивчення. Актуальним $є$ також уточнення структури понять і розроблення інструментарію їх вимірювання, що й становить перспективу подальших досліджень.

\section{СПИСОК ВИКОРИСТАНИХ ДЖЕРЕЛ}

[1] "Цифрова адженда України - 2020". [Електронний ресурс]. Доступно: https://www.google.com.ua/url? sa=t\&rct=j\&q=\&esrc $=$ s\&source $=$ web $\& c d=4 \& c a d=r j a \& u a c t=8 \& v e d=0 a h$ UKEwjdz-

fAzvTUAhUlSJoKHZorBZUQFgg2MAM\&url=https\%3A\%2F\%2Fucci.org.ua\%2Fuploads $\% 2$ Ffiles $\% 2 \mathrm{~F}$ 58e78ee3c3922.pdf\&usg=AFQjCNFO0abN4Um5ZfcCMuSmIULVeqQ_Yg.

[2] "Нова українська школа: концептуальні засади реформування загальної школи" [Електронний pecypc]. Доступно: http://mon.gov.ua/\%D0\%9D\%D0\%BE\%D0\%B2\%D0\%B8\%D0\%BD\%D0\%B8\%202016/08/17/mon.pdf.

[3] J. Stommel, “Critical Digital Pedagogy: a definition”, Hybrid Pedagogy. A digital journal of learning, teaching and technology, Nov.2014. [Online]. Available: http://www.hybridpedagogy.com/journal/critical-digital-pedagogy-definition/

[4] V. Bykov, M. Leshchenko,"Digital Humanistic Pedagogy: Relevant Problems of Scientific Research in the Field of Using ICT in Education", Information Technologies and LearningTools, vol. 53, no. 3, pp. 117, 2016. [Електронний ресурс]. Доступно: http://journal.iitta.gov.ua/index.php/ittl/article/view/1417.

[5] П. Матюшко, "Інтерактивна i цифрова педагогіка для нового покоління" [Електронний pесурс].Доступно: http://liftzvar.com.ua/uk/content/interaktyvna-i-cyfrova-pedagogika-dlya-novogopokolinnya.

[6] M. Tchoshanov, Engineering of Learning: Conceptualizing e-Didactics. Moscow, RF: UNESCO Institute for Information Technologies in Education, 2013. [Електронний ресурс]. Доступно: http://iite.unesco.org/pics/publications/en/files/3214730.pdf

[7] Національний інститут стратегічних досліджень (2014, Вересень). Аналітична записка «Питання розвитку цифрової культури украӥнського соиіуму» [Електронний ресурс]. Доступно: http://www.niss.gov.ua/articles/1631/

[8] Н. Соколова, "Цифровая культура или культура в цифровую эпоху? " [Электронный ресурс]. Доступно: http://culturalresearch.ru/files/open_issues/03_2012/IJCR_03(8)_2012_SokolovaN.pdf

[9] Д. В. Галкин,“Digital Culture: методологические вопросы исследования культурной динамики от цифрових автоматов до техно-био-тварей”,Международный журнал исследователей культуры, № 3(8),c. 11-16, 2012. [Электронный ресурс]. Доступно: http://culturalresearch.ru/files/open_issues/03_2012/IJCR_03(8)_2012_Galkin.pdf

[10] С. И. Черных, В. И. Паршиков, "Цифровая культура как гуманитарный феномен”,Профессиональное образование в современном мире, т. 6, № 4,c. 601-607, 2016.DOI: 10.15372/PEMW20160405.

[11] C. Gere,DigitalCulture. London, UK:ReactionBooksLtd, 2002.

[12] Л. В. Баева,“Электронная культура: опыт философского анализа”, Вопросы философии, № 5, с. 7583,2013 . [Электронный pecypc].

Доступно: http://vphil.ru/index.php?option=com_content\&task=view\&id=753\&Itemid=52.

[13] А. А. Гук, "Медийная культура кактехногенный феномен”, Медиа. Информация. Коммуникация (MIC), № 16, 2016. [Электронный ресурс]. Доступно: http://mic.org.ru/new/542-medijnaya-kulturakak-tekhnogennyj-fenomen.

[14] В. В. Кривошеев, “Электронная культура: необходимость междисциплинарного подхода к изучению", Вестник Балтийского федерального университета им. И. Канта. Серия: Гуманитарные и общественные науки, № 6, с. 76-81, 2013. [Электронный ресурс]. Доступно: https://cyberleninka.ru/article/v/elektronnaya-kultura-neobhodimost-mezhdistsiplinarnogo-podhoda-kizucheniyu.

[15] K. Litvinova, “Про компоненти цифрової культури”, Digitle Blog. [Електронний pecypc]. Доступно: https://digitle.wordpress.com/2016/10/04/12499875/. 
[16] В. А. Ребрина,“Цифрова культура педагога”, Навчальна програма, Хмельницький, Україна, 2014. [Електронний ресурс]. Доступно: http://dn.hoippo.km.ua/ckp/index.html.

[17] Н. Корецкая, О. Мороз, “Энафизм и нормы цифровой грамотности”,CultLook: научное бюро цифровых гуманитарных исследований [Электронный ресурс]. Доступно: http://cultlook.org/nk_om_enoughism.

[18] H. Jenkins, R. Purushotma, M. Weigeletal., "Confronting the Challenges of Participatory Culture: Media Education for the 21st Century",Foundation Reports on Digital Media and Learning. Cambridge, MA,London: The MIT Press, 2009.

[19] D. Belshaw, The Essential elements of digital literacies, 2011.[Електронний ресурс]. Доступно: http://digitalliteraci.es/.

[20] А. В. Шариков, “О четырехкомпонентной моделиц ифровой грамотности” ,The Journal of Social Policy Studies, vol. 14, no. 1, pp.87-98, March, 2016. [Електронний ресурс]. Доступно: https://jsps.hse.ru/article/view/3289.

[21] О. В. Овчарук, “Інформаційно-комунікаційна компетентність як предмет обговорення: міжнародні підходи”, у Формування інформаційно-комунікаційних компетентностей у контексті євроінтеграційних процесів створення інформаційного освітнього простору, В. Ю. Биков, О. В. Овчарук, Ред. Київ, Україна: Атіка, 2014, с. 7-16.

[22] В. О. Кудлай, “Цифрова грамотність особистості в контексті розвитку інформаційного суспільства", Вісник Маріупольського державного університету. Серія: філософія, культурологія, соиіологія, вип. 10, с. 97-104, 2015.

[23] О. Г. Радзієвська, "Інформаційна грамотність та цифрова нерівність: убезпечення дитини в сучасному інформаційному просторі”, Інформація і право, № 1 (20), с. 92-103, 2017. [Електронний pecypc]. - Доступно: http://ippi.org.ua/radzi\%D1\%94vska-og-informatsiina-gramotnist-ta-tsifrovanerivnist-ubezpechennya-ditini-v-suchasnomu-infor.

[24] C. Scott, “The Futures of Learning 3: What kind of pedagogies for the 21st century?",UNESCO Education Research and Foresight, Paris. [ERF Working Papers Series, no. 15]. [Online]. Available: http://unesdoc.unesco.org/images/0024/002431/243126e.pdf).

[25] A. Martin, J. Grudziecki,"Concepts and Tools for Digital Literacy Development”,Innovations in Teaching and Learning inInformation and Computer Sciences, vol. 5, no. 4, pp. 246-264, 2006.

[26] K. Ala-Mutka, "Mapping Digital Competence: Towards a Conceptual Understanding. Luxemburg: IPTSJRC", 2011. [Електронний ресурс]. Доступно: http://ipts.jrc.ec.europa.eu/publications/pub.cfm?id=4699.

[27] A. Ferrari, Digital Competence in Practice: An Analysis of Frameworks. Luxemburg: IPTS-JRC, 2011. [Електронний ресурс]. Доступно: http://ftp.jrc.es/EURdoc/JRC68116.pdf.

[28] С. М. Прохорова, "Поняття цифрової компетентності вчителя іноземної мови у світовому освітньому просторі”, Вісник Житомирського державного університету імені Івана Франка. Педагогічні науки,вип. 4, с. 113-116, 2015. [Електронний ресурс]. Доступно: http://nbuv.gov.ua/UJRN/VZhDUP_2015_4_24.

Матеріал надійшов до редакиії 09.07.2017p.

\title{
ЦИФРОВАЯ КУЛЬТУРА, ЦИФРОВАЯ ГРАМОТНОСТЬ, ЦИФРОВАЯ КОМПЕТЕНТНОСТЬ КАК ФЕНОМЕНЫ СОВРЕМЕННОГО ОБРАЗОВАНИЯ
}

\author{
Гаврилова Людмила Гавриловна \\ доктор педагогических наук, доцент, заведующий кафедрой теории и практики начального образования \\ ГВУЗ «Донбасский государственный педагогический университет», г. Славянск, Украина \\ ORCID ID 0000-0003-1814-5323 \\ lusjamuz64@gmail.com \\ Топольник Яна Владимировна \\ кандидат педагогических наук, доцент кафедры педагогики высшей школы \\ ГВУЗ «Донбасский государственный педагогический университет», г. Славянск, Украина \\ ORCID ID 0000-0001-7885-9454 \\ yannetkatop@gmail.com
}

Аннотация. В статье проанализированы дефиниции современного образования: цифровая культура, цифровая грамотность и цифровая компетентность. На основе изучения научных 
и нормативно-правовых документов автор доказывает, что названные понятия выходят за пределы узко технологической или цифровой отрасли, затрагивая широкий круг педагогических, культурологических, социогуманитарных и пр. аспектов. Основные смысловые акценты цифровой культуры автор связывает с возникновением новых специфических информационно-виртуальных форм культуры, а также новых видов культурной. Цифровая грамотность указывает, прежде всего, на умелое пользование электронными средствами, на сформированность умений и навыков работы с «цифрой». Определение цифровой компетентности исходит из общепринятого понимания компетентности и состоит из соответствующих знаний, умений, опыта, ценностей и отношений, целостно реализованных на практике.

Ключевые слова: цифровая компетентность; цифровая грамотность; цифровая культура; знания; умение; навыки; отношение.

\title{
DIGITAL CULTURE, DIGITAL LITERACY, DIGITAL COMPETENCE AS THE MODERN EDUCATIONAL PHENOMENA
}

\author{
Liudmyla H. Havrilova \\ SHEE “Donbas State Pedagogical University”, Sloviansk, Ukraine \\ ORCID ID 0000-0003-1814-5323 \\ lusjamuz64@gmail.com \\ Yana V. Topolnik \\ $\mathrm{PhD}$ in Pedagogics, Associate Professor of the Higher School Pedagogy Department \\ SHEE “Donbas State Pedagogical University”, Sloviansk, Ukraine \\ ORCID ID0000-0001-7885-9454 \\ yannetkatop@gmail.com
}

Dr. hab. in Pedagogics, Associate Professor, Head of the Primary Education Theory and Practice Department

\begin{abstract}
In the article the modern educational definitions - digital culture, digital literacy and digital competence - have been analyzed. Based on the study of scientific sources, state legal documents, the author proves that the above mentioned concepts go beyond the technological or digital branch. They cover a wide range of cultural, socio-humanitarian, communicative and other aspects. The phenomenon of digital culture is associated with the emergence of new specific information and virtual forms of culture, as well as new types of cultural communication. Digital literacy indicates the perfect use of electronic tools, the formation of abilities and skills to work with "digit". Digital competence is more general concept, whose definition consists of relevant knowledge, skills, experience, values and attitudes that can be holistically implemented into the practice.
\end{abstract}

Keywords: digital competence; digital literacy; digital culture; knowledge; abilities; skills; attitude.

\section{REFERENCES (TRANSLATED AND TRANSLITERATED)}

[1] Digital Agenda of Ukraine $\quad-\quad 2020 . \quad$ [Online]. Available: https://www.google.com.ua/url?sa=t\&rct=j\&q=\&esrc=s\&source=web\&cd=4\&cad=rja\&uact=8\&ved=0ah UKEwjdz-

fAzvTUAhU1SJoKHZorBZUQFgg2MAM\&url=https\%3A\%2F\%2Fucci.org.ua\%2Fuploads\%2Ffiles\%2F 58e78ee3c3922.pdf\&usg=AFQjCNFO0abN4Um5ZfcCMuSmIULVeqQ_Yg (in Ukrainian).

[2] New Ukrainian School: Conceptual Principles for General School Reform [Online]. Available:http://mon.gov.ua/\%D0\%9D\%D0\%BE\%D0\%B2\%D0\%B8\%D0\%BD\%D0\%B8\%202016/08/1 7/mon.pdf(inUkrainian).

[3] J. Stommel, "Critical Digital Pedagogy: a definition”, Hybrid Pedagogy. A digital journal of learning, teaching and technology, [Online]. Available:http://www.hybridpedagogy.com/journal/critical-digital-pedagogy-definition/ (in English). 
[4] V. Bykov, M. Leshchenko, "Digital Humanistic Pedagogy: Relevant Problems of Scientific Research in the Field of Using ICT in Education", Information Technologies and Learning Tools, vol. 53, no. 3, pp. 117, 2016. [Online]. Available: http://journal.iitta.gov.ua/index.php/itlt/article/view/1417 (in English).

[5] P. Matyushko, Interactive and digital pedagogy for the new generation [Online]. Available:http://liftzvar.com.ua/uk/content/interaktyvna-i-cyfrova-pedagogika-dlya-novogopokolinnya(in Ukrainian).

[6] M. Tchoshanov, Engineering of Learning: Conceptualizing e-Didactics. Moscow, RF: UNESCO Institute for Information Technologies in Education, 2013. [Online]. Available: http://iite.unesco.org/pics/publications/en/files/3214730.pdf(inEnglish).

[7] National Institute for Strategic Studies (Sept. 2014). Analytical note "Issues of development of digital culture of Ukrainian society”[Online]. Available: http://www.niss.gov.ua/articles/1631/ (in Ukrainian).

[8] N. Sokolova, Digital Culture or Culture in the Digital Age? [Online]. Available:http://culturalresearch.ru/files/open_issues/03_2012/IJCR_03(8)_2012_SokolovaN.pdf (inRussian).

[9] D. V. Galkin, "Digital Culture: Methodological issues of research of cultural dynamics from digital machines to techno-bio-creatures", Mezhdunarodnyj zhurnal issledovatelej kul'tury, no. 3(8), pp. 11-16, $2012 . \quad$ [Online]. http://culturalresearch.ru/files/open_issues/03_2012/IJCR_03(8)_2012_Galkin.pdf(inRussian).

[10] S. I. Chernyh, V. I. Parshikov, "Digital Culture as a Humanitarian Phenomenon", Professional'noe obrazovanie v sovremennom mire, vol. 6, no. 4, pp. 601-607, 2016. DOI: 10.15372/PEMW20160405 (in Russian).

[11] C. Gere, Digital Culture. London, UK: Reaction Books Ltd, 2002 (in English).

[12] L. V.Baeva, "Electronic culture: the experience of philosophical analysis", Voprosy filosofii, no. 5, pp. $75-83$, 2013. [Online]. Available: http://vphil.ru/index.php?option=com_content\&task=view\&id=753\&Itemid=52 (in Russian).

[13] A. A. Guk, "Media Culture as Technogenic Phenomenon", Media. Informacija. Kommunikacija(MIC),no. 16, 2016. [Online]. Available: http://mic.org.ru/new/542-medijnaya-kulturakak-tekhnogennyj-fenomen (inRussian).

[14] V. V. Krivosheev, "Electronic culture: the need for an interdisciplinary approach to learning", Vestnik Baltijskogo federal'nogo universiteta im. I. Kanta. Serija: Gumanitarnye i obshhestvennye nauki, no. 6, pp. 76-81, 2013. [Online]. Available: https://cyberleninka.ru/article/v/elektronnaya-kulturaneobhodimost-mezhdistsiplinarnogo-podhoda-k-izucheniyu (inRussian).

[15] K. Litvinova, About Components of Digital Culture", Digitle Blog. [Online]. Available: https://digitle.wordpress.com/2016/10/04/12499875/ (inUkrainian).

[16] V. A. Rebryna, "Digital culture of the teacher", Curriculum, Khmelnitsky, Ukraine, 2014. [Online].Available: http://dn.hoippo.km.ua/ckp/index.html(inUkrainian).

[17] N. Koreckaja, O. Moroz, "Enfism and the norms of digital literacy", Cult Look: nauchnoe bjuro cifrovyh gumanitarnyh issledovanij [Online]. Available: http://cultlook.org/nk_om_enoughism(inRussian).

[18] H. Jenkins, R. Purushotma, M. Weigeletal., "Confronting the Challenges of Participatory Culture: Media Education for the 21st Century", Foundation Reports on Digital Media and Learning. Cambridge, MA, London: The MIT Press, 2009 (in English).

[19] D. Belshaw, The Essential elements of digital literacies, 2011. [Online]. Available: http://digitalliteraci.es/(in English).

[20] A. V. Sharikov, “About four-component model of digital literacy”, The Journal of Social Policy Studies,vol. 14, no. 1, pp.87-98, March, 2016. [Online]. Available: https://jsps.hse.ru/article/view/3289(inRussian).

[21] O. V. Ovcharuk, "Information and communication competence as a subject of discussion: international approaches", inFormation of information and communication competencies in the context of European integration processes for the creation of informational educational space, V. Yu. Bykov, O. V. Ovcharuk,Eds. Kyiv, Ukraine: Atika, 2014, pp. 7-16 (in Ukrainian).

[22] V. O. Kudlai, "Digital literacy of the individual in the context of the development of the information society", Visnyk Mariupolskoho derzhavnoho universytetu. Seriia: filosofiia, kulturolohiia, sotsiolohiia,no. 10, pp. 97-104, 2015 (in Ukrainian).

[23] O. H. Radziievska, "Information literacy and digital In equality: safeguarding the child the modern in formation space", Informatsiia $i$ pravo, no. 1 (20), pp.92-103, 2017. [Online]. Available: http://ippi.org.ua/radzi\%D1\%94vska-og-informatsiina-gramotnist-ta-tsifrova-nerivnist-ubezpechennyaditini-v-suchasnomu-infor (in Ukrainian). 
[24] C. Scott, "The Futures of Learning 3: What kind of pedagogies for the 21st century?", UNESCO Education Research and Foresight, Paris. [ERF Working Papers Series, no. 15]. [Online]. Available: http://unesdoc.unesco.org/images/0024/002431/243126e.pdf) (in English).

[25] A. Martin, J. Grudziecki, "Concepts and Tools for Digital Literacy Development", Innovations in Teaching and Learning in Information and Computer Sciences, vol. 5, no. 4, pp. 246-264, 2006 (in English).

[26] K. Ala-Mutka, Mapping Digital Competence: Towards a Conceptual Understanding. Luxemburg: IPTSJRC, 2011. [Online]. Available: http://ipts.jrc.ec.europa.eu/publications/pub.cfm?id=4699(in English).

[27] A. Ferrari, Digital Competence in Practice: An Analysis of Frameworks. Luxemburg: IPTS-JRC, 2011. [Online]. Available:: http://ftp.jrc.es/EURdoc/JRC68116.pdf (in English).

[28] C. M. Prokhorova, "Concept of digital competence of a foreign language teacher in the world of educational space", Visnyk Zhytomyrskoho derzhavnoho universytetu imeni Ivana Franka. Pedahohichni nauky, no. 4, pp. 113-116, 2015. [Online]. Available: http://nbuv.gov.ua/UJRN/VZhDUP_2015_4_24 (in Ukrainian).

\section{$(\mathrm{Cc}) \mathrm{BY}-\mathrm{NC}-\mathrm{SA}$}

This work is licensed under Creative Commons Attribution-Non Commercial-Share Alike 4.0 International License. 